Review

\title{
Fungal Infections Other Than Invasive Aspergillosis in COVID-19 Patients
}

\author{
Kerri Basile $^{1}\left(\mathbb{D}\right.$, Catriona Halliday ${ }^{1,2}\left(\mathbb{D}\right.$, Jen Kok ${ }^{1,2}(\mathbb{D})$ and Sharon C-A. Chen ${ }^{1,2,3, *}$ \\ 1 Centre for Infectious Diseases and Microbiology Laboratory Services, NSW Health Pathology-Institute of \\ Clinical Pathology and Medical Research, Westmead, NSW 2145, Australia; \\ kerri.basile@health.nsw.gov.au (K.B.); Catriona.Halliday@health.nsw.gov.au (C.H.); \\ jen.kok@health.nsw.gov.au (J.K.) \\ 2 Centre for Infectious Diseases and Microbiology—Public Health, Westmead Hospital, \\ Westmead, NSW 2145, Australia \\ 3 Sydney Institute for Infectious Diseases, University of Sydney, Sydney, NSW 2006, Australia \\ * Correspondence: sharon.chen@health.nsw.gov.au
}

Citation: Basile, K.; Halliday, C.; Kok, J.; Chen, S.C.-A. Fungal Infections Other Than Invasive Aspergillosis in COVID-19 Patients. J. Fungi 2022, 8, 58. https://doi.org/10.3390/ jof 8010058

Academic Editor: Katrien Lagrou

Received: 6 December 2021

Accepted: 4 January 2022

Published: 6 January 2022

Publisher's Note: MDPI stays neutral with regard to jurisdictional claims in published maps and institutional affiliations.

Copyright: (C) 2022 by the authors. Licensee MDPI, Basel, Switzerland. This article is an open access article distributed under the terms and conditions of the Creative Commons Attribution (CC BY) license (https:// creativecommons.org/licenses/by/ $4.0 /)$.

\begin{abstract}
Invasive fungal disease (IFD) associated with Coronavirus Disease 2019 (COVID-19) has focussed predominantly on invasive pulmonary aspergillosis. However, increasingly emergent are non-Aspergillus fungal infections including candidiasis, mucormycosis, pneumocystosis, cryptococcosis, and endemic mycoses. These infections are associated with poor outcomes, and their management is challenged by delayed diagnosis due to similarities of presentation to aspergillosis or to non-specific features in already critically ill patients. There has been a variability in the incidence of different IFDs often related to heterogeneity in patient populations, diagnostic protocols, and definitions used to classify IFD. Here, we summarise and address knowledge gaps related to the epidemiology, risks, diagnosis, and management of COVID-19-associated fungal infections other than aspergillosis.
\end{abstract}

Keywords: COVID-19; SARS-CoV-2; fungal infections; non-Aspergillus fungi

\section{Introduction}

Severe acute respiratory syndrome coronavirus-2 (SARS-CoV-2), the virus responsible for Coronavirus Disease 2019 (COVID-19), was first identified in December 2019 in Wuhan, China and declared a pandemic by the World Health Organization (WHO) in March 2020 [1]. Despite the rapid development of pathogen-specific therapies and vaccinations beginning with emergency use authorisation of the Pfizer-BioNTech (Pfizer Inc., New York, NY, USA) COVID-19 mRNA BNT162b2 vaccine in December 2020 [2], there remains ongoing worldwide transmission of SARS-CoV-2 accelerated by the emergence of WHO designated variants of concern (VOC) [3] strains, which have fuelled increased risks to public health. The clinical spectrum of COVID-19 ranges from asymptomatic infection to severe respiratory illness and multiorgan failure; extrapulmonary disease may also occur $[4,5]$. Furthermore, morbidity is compounded in that COVID-19 per se, as well as the therapeutic agents used for its treatment, predisposes to other infections including fungal infections, which may co-exist or follow COVID-19 [6]. Uncommon early in the pandemic [6], fungal coinfections are now increasingly reported $[7,8]$ of which the most well characterized is invasive aspergillosis (IA) [9-13].

Opportunistic invasive fungal disease (IFD) in the setting of severe respiratory viral illness is not novel, being well described in the context of severe influenza, parainfluenza, and respiratory syncytial virus infections, and now, COVID-19 [10,14-18]. Whilst COVID19-associated pulmonary aspergillosis (CAPA) [13] was the first IFD to be reported and is the most well-established clinical entity, reports of fungal coinfections due to yeasts and non-Aspergillus filamentous fungi have increased [19-22]. The recognition of these 
IFDs is essential for early and targeted treatment, as antifungal drug choices differ from those for aspergillosis. In turn, this hinges upon the rapid, accurate identification of the etiological pathogen by laboratory tests given the common symptoms (fever, cough, and dyspnoea) [23] and radiological findings e.g., ground glass opacities [23,24] in CAPA and non-CAPA IFD. However, laboratory diagnosis is challenged by reticence in performing procedures such as bronchoscopies and induced sputum collection to prevent the nosocomial transmission of COVID-19.

Despite improvements in the understanding of CAPA and other COVID-19-associated fungal infections, knowledge gaps related to diagnosis, management, and prevention remain. We first briefly describe the pathophysiology of COVID-19 lung disease and the risks for IFD in COVID-19 patients (Sections 2 and 3). Then, we review COVID-19-associated IFD caused by fungi other than Aspergillus spp. focussing on the epidemiology, diagnostic, and management approaches (Section 4). Finally, we summarise the more pertinent microbiological and imaging findings that may assist the diagnosis of non-Aspergillus IFD in COVID-19 patients (Section 5).

\section{Pathophysiology of COVID-19 Lung Disease}

There are several pathophysiological mechanisms by which SARS-CoV-2 as well as its treatment can predispose to IFD, although our understanding of these pathways is incomplete. SARS-CoV-2 infection may be transmitted through contact, droplet, airborne, fomite, faecal-oral, bloodborne, mother-to-child, and animal-to-human routes [25]. Each SARS-CoV-2 virion has an outer surface covered with spike proteins. The S1 subunit hosts the receptor-binding domain (RBD) and is responsible for binding to the human angiotensin-converting enzyme 2 (ACE2) receptor, which is expressed in the lungs and other body sites for cell entry [26,27]. The S2 subunit allows viral fusion with the host cell membrane. Following this, SARS-CoV-2 utilises transmembrane serine protease 2 (TMPRSS2) or cathepsin L to merge the viral and cell membranes. The use of TMPRSS2 pathways leads to more rapid infection [28] as does an intact furin cleavage site within the $S$ protein, as seen in infection with the Alpha and Delta VOC.

The pathological features of COVID-19 are similar to those seen in infection with SARS-CoV and Middle Eastern respiratory syndrome-Coronavirus (MERS-CoV) [5,29], and they are characterised by cell injury and death by pyroptosis [30]. In brief, viral entry and replication leads to the activation of proinflammatory cytokines and chemokines such as interleukin-6 (IL-6), interleukin-8 (IL-8), type II interferon, and monocyte chemoattractant protein 1 [31]. In turn, this leads to the pulmonary recruitment of macrophages and dendritic cells, which are the key components for host innate defences against respiratory infections [32] with the direct viral infection of macrophages and/or dendritic cells [33] or phagocytization of apoptotic-infected cells [34]. These pathways result in further cytokine and chemokine release, whilst the late phase $\mathrm{T}$ cell-mediated response is initiated by antigen presentation via dendritic cells and macrophages to promote the production of virus-specific antibody and CD8+ T cells that kill infected alveolar cells. Finally, IL-8, a chemoattractant for neutrophils and T cells, can contribute to lung injury $[35,36]$, with up to $5 \%$ of patients experiencing severe lung damage [37].

\section{COVID-19 Therapies and Risk of IFD}

Therapies used to treat patients with SARS-CoV-2 infection comprise three main categories: (i) antiviral treatments, (ii) immune modulators such as corticosteroids and janus kinase (JAK) inhibitors, and (iii) monoclonal antibody treatments; these can prevent SARS$\mathrm{CoV}-2$ from entering cells, hence causing serious disease. Immunotherapies are increasingly used, and whilst they block undesired inflammatory effects, they have the potential to increase the risk of IFDs-in particular, corticosteroids such as dexamethasone are routinely used in patients with COVID-19 infection who are receiving oxygen to modulate the systemic inflammatory response [38]. IL-6 inhibitors e.g., tocilizumab, reduce the cascade of cytokine release and JAK inhibitors e.g., baricitinib inhibit cell signalling processes [39]. The 
currently available drugs including repurposed drugs to treat COVID-19 and their reported associations with IFD are summarized in Table 1. Broadly, immunotherapies increase risk of IFDs through resultant cytopaenias, inhibition of cell signalling, and inhibition of function of T cells, B cells, and/or phagocytes, all of which can lead to increased airway colonization of fungus [40]. Since many of the novel therapies for COVID-19 only have emergency use authorisation rather than full regulatory approval, close monitoring of their use is required to identify adverse consequences including that of subsequent IFD.

Table 1. Summary of therapies used for COVID-19.

\begin{tabular}{|c|c|c|c|}
\hline Drug Category & Drugs & Mechanism of Action & Fungal Infections Reported \\
\hline Antiviral drugs & $\begin{array}{l}\text { remdesivir, (Veklury }{ }^{\circledR}, \\
\text { Gilead Sciences Inc.) }\end{array}$ & $\begin{array}{l}\text { Nucleoside anti-proviral drug } \\
\text { Inhibits SARS-CoV-2 replication via } \\
\text { RNA-dependent RNA polymerase (RdRp) }\end{array}$ & Nil reported \\
\hline \multirow{3}{*}{$\begin{array}{l}\text { Immune } \\
\text { modulators }\end{array}$} & $\begin{array}{l}\text { Glucocorticoids } \\
\text { e.g., } \\
\text { predinisone } \\
\text { prednisolone } \\
\text { dexamethasone }\end{array}$ & $\begin{array}{l}\text { Decrease vasodilation, permeability of } \\
\text { capillaries, and leukocyte migration } \\
\text { Inhibit neutrophil apoptosis and } \\
\text { demargination; inhibit phospholipase } \mathrm{A}_{2} \\
\text { function, and inhibit NF-Kappa B and } \\
\text { inflammatory transcription factors } \\
\text { Promote expression of anti-inflammatory } \\
\text { genes such as that for IL-10. }\end{array}$ & $\begin{array}{l}\text { Candidiasis } \\
\text { Pneumocystosis } \\
\text { Invasive aspergillosis } \\
\text { Mucormycosis } \\
{[41,42]}\end{array}$ \\
\hline & $\begin{array}{l}\text { baricitinib, } \\
\text { (Olumiant }^{\circledR}, \text { Eli Lilly and } \\
\text { Company) }\end{array}$ & \multirow{2}{*}{$\begin{array}{l}\text { JAK inhibitors: } \\
\text { Bind to JAK, which prevents the activation of } \\
\text { the JAK-STAT signalling pathway, which } \\
\text { reduces the production of proinflammatory } \\
\text { cytokines }\end{array}$} & $\begin{array}{l}\text { Candidiasis } \\
\text { Pneumocystosis } \\
\text { Histoplasmosis } \\
\text { Cryptococcosis ** } \\
{[43,44]}\end{array}$ \\
\hline & $\begin{array}{l}\text { tofacitinib, } \\
\left(\text { Xeljanz }^{\circledR}, \text { Pfizer }\right)\end{array}$ & & $\begin{array}{l}\text { Oesophageal candidiasis } \\
\text { Cryptococcosis } \\
{[45-47]}\end{array}$ \\
\hline \multirow{5}{*}{$\begin{array}{c}\text { Monoclonal } \\
\text { antibodies (mAb) }\end{array}$} & $\begin{array}{l}\text { tocilizumab, (Actemra }{ }^{\circledR}, \\
\text { Roche) }\end{array}$ & $\begin{array}{l}\text { IL-6 receptor antagonist. } \\
\text { Results in reduction in cytokine and acute } \\
\text { phase reactant production. }\end{array}$ & $\begin{array}{l}\text { Invasive candidiasis } \\
\text { Cryptococcosis } \\
\text { Pneumocystosis } \\
{[47-49]}\end{array}$ \\
\hline & $\begin{array}{l}\text { sotrovimab, } \\
\left(\text { Xevudy }{ }^{\circledR},\right. \\
\text { GlaxoSmithKline })\end{array}$ & $\begin{array}{l}\text { Engineered human IgG1 monoclonal } \\
\text { antibody that binds to the spike protein } \\
\text { receptor binding domain (RBD) of } \\
\text { SARS-CoV-2 }\end{array}$ & Nil reported to date \\
\hline & $\begin{array}{l}\text { sarilumab, }\left(\text { Kevzara }^{\circledR},\right. \\
\text { Sanofi and Regeneron } \\
\text { Pharmaceuticals, Inc.) }\end{array}$ & $\begin{array}{l}\text { IL-6 receptor antagonist. } \\
\text { Results in reduction in cytokine and acute } \\
\text { phase reactant production. }\end{array}$ & $\begin{array}{l}\text { Candidiasis } \\
\text { Pneumocystis. }{ }^{* *} \\
{[50]}\end{array}$ \\
\hline & $\begin{array}{l}\text { casirivimab and } \\
\text { imdevimab } \\
\text { (REGEN-COV } \\
\text { Regeneron } \\
\text { Pharmaceuticals, Inc.) }\end{array}$ & \multirow{2}{*}{ 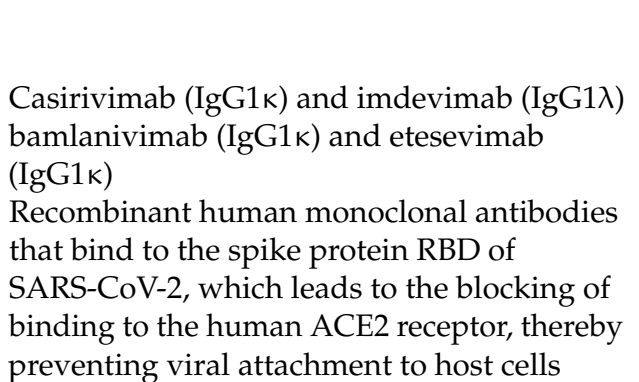 } & \multirow{2}{*}{ Nil reported to date } \\
\hline & $\begin{array}{l}\text { bamlanivimab and } \\
\text { etesevimab (Eli Lilly and } \\
\text { Company) }\end{array}$ & & \\
\hline
\end{tabular}

Key: ACE2-angiotensin-converting enzyme 2; IL-6, interleukin-6; IL-10, interleukin-10; JAK-janus kinase STAT - signal transducers and activators of transcription; ** patients with invasive fungal infections may present with disseminated rather than localised disease. 


\section{Scope and Pathogens}

\subsection{COVID-19-Associated Pulmonary Aspergillosis (CAPA)}

Much of the literature has focussed on CAPA detailing its burden, clinical features, diagnosis, and outcomes [8,51-54]. Whilst the present review is directed at non-Aspergillus IFDs, it is essential to acknowledge the lessons learned from CAPA, particularly with regard to limitations in diagnosis [23,55]. Other notable challenges with regard to the comparability of data include the definitions used to classify the likelihood of IFD in the setting of COVID-19, study design, and the patient population studied. Currently, the assignment of CAPA cases takes into consideration existing definitions for IA in critical care and influenza-associated pulmonary aspergillosis whilst leveraging the evolving knowledge of CAPA $[18,23,55,56]$.

With the above limitations in mind, the estimated incidence of CAPA is reported to be $\approx 10 \%$ (range 3-39\%) with an overall mortality of about $50 \%$ [53]; many of these patients were in the intensive care unit (ICU). Risk factors include traditional factors for IA such as transplants or haematological malignancies but also those of acute respiratory distress syndrome, mechanical ventilation, corticosteroid use [51,53,55], and possibly, tocilizumab receipt [57]. Consensus expert opinion recommends the use of prospective, multi-modal diagnostic approaches comprising both culture and non-culture-based antigen and nucleic acid amplification tests (NAATs), in conjunction with chest imaging (see Table 2 for the more common radiological abnormalities of CAPA) to be useful in diagnosis. Importantly, the probability of CAPA increases when the positivity of these tests is seen across multiple time points and across multiple sample types $[23,55,58]$. Hence, it is reasonable to envisage that for other IFDs, similar diagnostic approaches for assigning the probability of infection would apply. Other essential diagnostic tests are pathogen-specific biomarkers where they exist, and histopathological examination for, and culture of pathogens from sterile sites including blood (Table 2).

Table 2. Summary of risk factors in COVID-19 patients for invasive fungal disease and diagnostic approaches.

\begin{tabular}{|c|c|c|c|c|c|c|c|}
\hline & CAPA & IC & PCP & Cryptococcosis & $\begin{array}{l}\text { Endemic } \\
\text { Mycoses }\end{array}$ & $\begin{array}{c}\text { Non } \\
\text { Aspergillius } \\
\text { Mould } \\
\text { Infections }\end{array}$ & CAM \\
\hline \multicolumn{8}{|l|}{ RISK FACTORS } \\
\hline Corticosteroid receipt & $x$ & $x$ & $x$ & $x$ & $x$ & $x$ & $x$ \\
\hline $\begin{array}{l}\text { ICU MV or non MV + } \\
\text { (clinical deterioration) }\end{array}$ & $x$ & $X$ & $x$ & $x$ & $x$ & $x$ & $x$ \\
\hline IL-6 inhibitor therapy & $x$ & $X$ & & & $x$ & & \\
\hline HIV/severe lymphopenia & & & $x$ & $x$ & & & \\
\hline \multirow[t]{2}{*}{$\begin{array}{l}\text { Receipt of immunosuppressive } \\
\text { therapies }\end{array}$} & $x$ & $x$ & $x$ & $x$ & $x$ & $x$ & $x$ \\
\hline & CAPA & IC & PCP & Cryptococcosis & $\begin{array}{l}\text { Endemic } \\
\text { Mycoses }\end{array}$ & $\begin{array}{c}\text { Non } \\
\text { Aspergillius } \\
\text { Mould } \\
\text { Infections }\end{array}$ & CAM \\
\hline $\begin{array}{l}\text { Poorly controlled diabetes } \\
\text { mellitus }\end{array}$ & & & & & & & $x$ \\
\hline Major trauma & & & & & & $x$ & $x$ \\
\hline $\begin{array}{l}\text { Travel to endemic region or } \\
\text { previous } \\
\text { infection with endemic mycoses }\end{array}$ & & & & & $x$ & & \\
\hline
\end{tabular}


Table 2. Cont.

\begin{tabular}{|c|c|c|c|c|c|c|c|c|}
\hline & & CAPA & IC & PCP & Cryptococcosis & $\begin{array}{l}\text { Endemic } \\
\text { Mycoses }\end{array}$ & $\begin{array}{l}\text { Non } \\
\text { Aspergillius } \\
\text { Mould } \\
\text { Infections }\end{array}$ & CAM \\
\hline \multicolumn{9}{|c|}{ DIAGNOSTIC APPROACHES } \\
\hline \multirow{2}{*}{ Histopathology } & \multirow{2}{*}{$\begin{array}{l}\text { Characteristics } \\
\text { findings using } \\
\text { standard } \\
\text { stains }\end{array}$} & • & • & • & • & • & • & • \\
\hline & & $\begin{array}{l}\text { Hyaline, } \\
\text { acutely } \\
\text { branching } \\
\text { septate } \\
\text { hyphae }\end{array}$ & $\begin{array}{l}\text { Budding yeast } \\
\text { cells and/or } \\
\text { pseudohyphae }\end{array}$ & $\begin{array}{l}\text { Cysts and/or } \\
\text { trophozoites }\end{array}$ & $\begin{array}{l}\text { Encapsulated } \\
\text { yeast cells }\end{array}$ & $\begin{array}{l}\text { Budding yeast } \\
\text { cells or } \\
\text { spherules }\end{array}$ & $\begin{array}{l}\text { Hyaline, } \\
\text { branching } \\
\text { septate } \\
\text { hyphae }\end{array}$ & $\begin{array}{l}\text { Broad, } \\
\text { irregular, } \\
\text { pauci septate } \\
\text { hyphae }\end{array}$ \\
\hline \multirow{5}{*}{ Culture-based } & \multirow{2}{*}{$\begin{array}{l}\text { Characteristic } \\
\text { findings on } \\
\text { microscopy }\end{array}$} & • & $\bullet$ & $\bullet$ & $\bullet$ & • & • & • \\
\hline & & $\begin{array}{l}\text { Hyaline, } \\
\text { acutely } \\
\text { branching } \\
\text { septate } \\
\text { hyphae }\end{array}$ & $\begin{array}{l}\text { Budding yeast } \\
\text { cells and/or } \\
\text { pseudohyphae }\end{array}$ & $\begin{array}{l}\text { Cysts and/or } \\
\text { trophozoites }\end{array}$ & $\begin{array}{l}\text { Encapsulated } \\
\text { yeast cells }\end{array}$ & $\begin{array}{l}\text { Budding yeast } \\
\text { cells or } \\
\text { spherules }\end{array}$ & $\begin{array}{l}\text { Hyaline, } \\
\text { branching } \\
\text { septate } \\
\text { hyphae }\end{array}$ & $\begin{array}{l}\text { Broad, } \\
\text { irregular, } \\
\text { pauci septate } \\
\text { hyphae }\end{array}$ \\
\hline & $\begin{array}{c}\text { Respiratory } \\
\text { tract }\end{array}$ & $\bullet$ & $\bullet$ & & $\bullet$ & • & $\bullet$ & $\bullet$ \\
\hline & $\begin{array}{l}\text { Sterile sites } \\
\text { other than } \\
\text { blood }\end{array}$ & & & & $\bullet$ & & $\bullet$ & $\bullet$ \\
\hline & Blood & & $\bullet$ & & $\bullet$ & & $\bullet$ & \\
\hline \multirow{6}{*}{$\begin{array}{l}\text { Non-culture- } \\
\text { based }\end{array}$} & Aspergillus Ag & $\bullet$ & & & & & & \\
\hline & $\begin{array}{c}\text { Cryptococcal } \\
\text { Ag }\end{array}$ & & & & - & & & \\
\hline & $\begin{array}{c}\text { EIA for } \\
\text { antibody } \\
\text { detection or } \\
\text { Ag testing for } \\
\text { Coccidioides } \\
\text { and/or } \\
\text { Histoplasma }\end{array}$ & & & & & $\bullet$ & & \\
\hline & $\begin{array}{l}\text { Serum } 1,3, \\
\beta \text {-D-glucan }\end{array}$ & $\bullet$ & $\bullet$ & $\bullet$ & & & $\bullet$ & \\
\hline & $\begin{array}{c}\text { Genus-specific } \\
\text { NAAT }\end{array}$ & $\bullet$ & $\bullet$ & $\bullet^{n}$ & $\bullet$ & $\bullet$ & $\bullet$ & $\bullet$ \\
\hline & $\begin{array}{c}\text { Panfungal } \\
\text { PCR (ITS1/2) }\end{array}$ & $\bullet$ & $\bullet$ & $\bullet$ & $\bullet$ & $\bullet$ & $\bullet$ & $\bullet$ \\
\hline \multicolumn{2}{|c|}{$\begin{array}{l}\text { RADIOLOGY } \\
\text { (typical or more common } \\
\text { abnormalities on chest CT) }\end{array}$} & $\begin{array}{c}\text { Peripheral, } \\
\text { bilateral GGO } \\
+/- \\
\text { consolidation } \\
\text { or visible } \\
\text { intralobular } \\
\text { lines (i.e., } \\
\text { crazy paving) } \\
\text { in early stages. } \\
\text { Multifocal } \\
\text { GGO (round) } \\
+/- \\
\text { consolidation } \\
\text { or intralobular } \\
\text { lines at peak } \\
\text { stage. } \\
\text { Reverse halo } \\
\text { sign +/- } \\
\text { organising } \\
\text { pneumonia at } \\
\text { late stage }\end{array}$ & $\begin{array}{l}\text { As directed by } \\
\text { clinical } \\
\text { findings; } \\
\text { organ } \\
\text { involvement } \\
\text { rare }\end{array}$ & $\begin{array}{l}\text { Diffuse GGO } \\
\text { Interstitial } \\
\text { infiltrates (pre- } \\
\text { dominantly } \\
\text { upper lobes } \\
\text { and perihilar } \\
\text { regions) }\end{array}$ & $\begin{array}{l}\text { Nodules ( } 1 \text { or } \\
\text { more) } \\
\text { Cryptococcomas, } \\
\text { Pulmonary } \\
\text { infiltrates }\end{array}$ & $\begin{array}{l}\text { Focal or } \\
\text { diffuse } \\
\text { airspace } \\
\text { disease } \\
\text { Upper lobe } \\
\text { cavitation } \\
\text { thick-walled } \\
\text { bullae, } \\
\text { lymphadenopathy }\end{array}$ & $\begin{array}{l}\text { Similar to } \\
\text { CAM and } \\
\text { CAPA }\end{array}$ & $\begin{array}{c}\text { GGO, } \\
\text { mass lesions } \\
+ \text { /- cavitation } \\
\text { Consolidation, } \\
\text { Reverse halo } \\
\text { sign may be } \\
\text { present. \#\# }\end{array}$ \\
\hline
\end{tabular}

Key: Ag-antigen; CAPA—COVID-19-associated pulmonary aspergillosis; CAM-COVID-19-associated mucormycosis; CT—computerised tomography; EIA—enzyme immunoassay; GGO—ground glass opacities; HIV— human immunodeficiency virus; IC — invasive candidiasis; ICU MV or non MV—intensive care unit admission with mechanical ventilation or without mechanical deterioration + clinical deterioration (e.g., pulmonary desaturation, sepsis-like syndrome); IL-6 (interleukin 6, i.e., Tocilizumab, and Sarilumab); ITS-internal transcribed spacer region; NAAT—nucleic-acid amplification test; $\mathrm{PCP}$-Pneumocystis jirovecii pneumonia; $\mathrm{X}$ - denotes the presence of the risk factor well established to be associated with the fungal infection; $\bullet$ - denotes a recommended test; ^-quantitative PCR; ** Findings can be atypical; lobular or segmental consolidation in predominantly cavitating, tree in bud opacities with peri hilar nodules; \#\#-in suspected CAM—other sites including the sinuses and brain must also be imaged in addition to the chest. 


\subsection{Invasive Candidiasis}

After CAPA, invasive candidiasis (IC) is the second most reported fungal coinfection with COVID-19, [9,10,59-61] including infections caused by drug-resistant Candida species [60,62]. Risk factors for IC are inevitably present in critically ill COVID-19 patients admitted to the ICU and include mechanical ventilation, indwelling devices, broadspectrum antibiotic therapy, and glucocorticoid use [63,64]. The incidence of COVID-19associated candidiasis (CAC) has ranged from $0.7 \%(7 / 989)$ in Spain to $12.6 \%(17 / 135)$ and $23.5 \%$ (4/17) in the United Kingdom and China, respectively [63]. Candidemia has predominated amongst the clinical forms of IC with a higher frequency in ICU settings.

Reports suggest there has been a two to 10-fold increase in the incidence of candidemia in patients with COVID-19 with candidemia developing earlier (within two weeks of hospitalisation in the ICU) than in patients without COVID-19 $[41,59,65]$. The reasons for this are uncertain as differences in underlying comorbidities, disease severity, and classical risk factors for IC between these cohorts have not been identified. Instead, the higher rate may reflect an additive effect of multiple risk factors that may be prolonged and protracted e.g., ICU stay and invasive mechanical ventilation $[59,66]$. In a large US study of 251 patients with candidemia, 25.5\% (64/251) were coinfected with COVID-19 [67]. These patients were less likely to have underlying conditions such as chronic liver disease, solid organ malignancies, as well as traditional risks e.g., prior surgery but more likely to have risk factors linked to treatment for severe COVID-19 that is, tocilizumab and corticosteroids, and mechanical ventilation compared with those without COVID-19; the mortality rate was $62.5 \%$ vs. $32.1 \%$ [67]. Of note, Kayaaslan et al. demonstrated that corticosteroid treatment was an independent risk factor associated with mortality in patients with candidemia [41]. Other studies have reported mortality rates among patients with Candida and COVID-19 of 46-92.5\%; the highest rates were in those with C. glabrata and C. auris infections $[41,63,65,68]$.

C. albicans has been the most common pathogenic species $44.1 \%(19 / 43)$, followed by C. auris $23.2 \%$ (10/43), C. glabrata, C. parapsilosis, and C. tropicalis $4.6 \%(2 / 43)$ each [63]. However, in India, multi-drug-resistant $C$. auris was the most prevalent species [63], and this species has also recently displaced C. albicans as the most common Candida species in at least one hospital in Spain [69]. It is curious that at the present time of heightened infection prevention measures in hospitals, $C$. auris has emerged as one of the more frequent causative species in hospitals. One hypothesis, yet unproven, is that with enhanced infection control approaches in the COVID-19 setting, paradoxically, those that minimise the exchange of certain practices e.g., keeping on a base layer of gown between patients, may possibly promote the spread of $C$. auris [70].

The diagnosis of IC may be challenging, relying on both conventional culture from blood or other samples, and culture-independent tests including Candida mannan and anti-mannan IgG, serum (1,3)- $\beta$-D-glucan (BDG), and NAAT-based assays, such as the T2Candida assay [71] (Table 2). The diagnostic sensitivity and specificity may be further increased when serum BDG is combined with procalcitonin to help differentiate fungal from bacterial infections [72]. The high negative predictive value of BDG for diagnosing IC, in the ICU population, may guide the early discontinuation of empiric antifungal therapy if pre-treatment serum BDG is negative [73]. As patient inflammatory responses (e.g., fever) may be blunted following the receipt of immune-modulating agents, a high index of suspicion for IC is required particularly for critically ill COVID-19 patients. Cultures from blood and other sties should be undertaken (Table 2), and empiric anti-Candida therapy may be initiated according to institutional protocols.

The treatment of candidemia and other forms of IC is informed by available guidelines, as is addressing modifiable risk factors for source control and to prevent the occurrence of candidemia [68,74]. Echinocandins (anidulafungin, caspofungin, or micafungin) have been the primary antifungals used to treat $C A C$ with liposomal amphotericin $B$ and the azoles (e.g., fluconazole, isavuconazole, posaconazole, and voriconazole) are used as second line alternatives informed by susceptibility test results [64]. As for non-COVID-19 patients with candidemia, the removal of indwelling vascular catheters is essential where 
possible [63]. Infections due to multi-drug-resistant species, particularly C. auris, remain a management challenge.

\subsection{Pneumocystis Pneumonia}

Uncommon in COVID-19 patients compared with CAPA, Pneumocystis jirovecii pneumonia (PCP) coinfection was first diagnosed by real-time PCR at autopsy in a patient with severe dyspnoea [75]. Since then, positive PCR tests for PCP have been increasingly reported in association with COVID-19, including in patients with underlying human immunodeficiency virus (HIV) infection [76-80]. Reported frequencies of positive $P$. jirovecii PCR findings have ranged from $1.4 \%(2 / 145)$ [81] to $9.3 \%(10 / 108)$ [82], but the true incidence of $P$. jirovecii infection as opposed to the detection of $P$. jirovecii DNA in clinical samples which can represent colonisation only is unknown [83]. A review [77] of 12 COVID19 patients with $\mathrm{PCP}$ found all required invasive mechanical ventilation, and many had HIV (58.3\%) or were in receipt of long-term immunosuppressive agents such as corticosteroids $(91.7 \%)$. In the above patients, severe lymphopenia $\left(<1000\right.$ cells $\left./ \mathrm{mm}^{3}\right)$ was present with a CD4+T cell count of $<200$ cells $/ \mathrm{mm}^{3}$ [77], where severe CD4+ lymphopenia is a well-known risk for PCP [80]. It is hypothesised that the development of lymphopenia requiring adjunctive steroids and/or immunomodulatory therapies in COVID-19 patients may re-activate or "activate" asymptomatic $P$. jirovecii infection in colonised patients [82].

The diagnosis of PCP is similar to that in non-COVID-19 populations with combined assessment of clinical features, radiologic findings, and laboratory tests. Diagnosis is challenging because of the similar clinical (e.g., cough, dyspnoea) and radiological presentations of PCP and COVID-19. Undertaking chest computerised tomography (CT) scanning is essential, with extensive diffuse ground glass opacities and interstitial infiltrates being typical, most predominantly in the upper lobes and perihilar regions [76,84]. However, it is important to acknowledge that imaging abnormalities cannot distinguish PCP from COVID-19 pneumonia, and establishing a diagnosis of PCP relies on microbiological approaches. The detection of $P$. jirovecii cysts and/or trophozoites in tissue, bronchoalveolar lavage (BAL) fluid, or expectorated sputum using conventional microscopy or immunofluorescence staining provides a definitive diagnostic of infection but lacks sensitivity, particularly in non-HIV patients [71]. However, the diagnosis of PCP by PCR alone is not sufficiently definitive, as it is unable to discriminate between colonisation and infection; although quantitative PCR (qPCR) allows an estimate of fungal burden, clinical cut-off values have not been established. Nonetheless, a negative qPCR result can rule out PCP. A high fungal load is helpful to establish probable disease, but a lower fungal load detected by qPCR requires additional diagnostic indicators $[71,85]$. A positive serum $B D G(\geq 80 \mathrm{pg} / \mathrm{mL})$ result can contribute to the diagnosis, particularly when combined with a positive PCR result, and negative BDG results can exclude infection in at-risk patients [71,86]. In COVID-19 patients, the utility of serum BDG to diagnose PCP is particularly appealing as it negates the need to perform invasive procedures [80]. However, more study is required to assess the clinical utility of both qPCR and BDG testing in COVID-19/PCP coinfections. Finally, the occurrence of PCP reminds us of the importance of testing for HIV / AIDS, regardless of COVID-19.

Antifungal therapy should follow a similar approach to patients without COVID19 [87]. Trimethoprim-sulfamethoxazole often in conjunction with corticosteroids remains the preferred first-line treatment of PCP $[87,88]$, although there is debate as to whether to treat patients coinfected with COVID-19 or not, as some patients have improved without treatment [81-83]. When there is a high clinical suspicion for PCP, treatment can be initiated before making a definitive diagnosis, and clinical improvement can be expected within $4-8$ days [77]. To date, the use of trimethoprim-sulfamethoxazole has not been associated with adverse outcomes. 


\subsection{Non-Aspergillus Mould Infections}

In comparison with CAPA, coinfection or superimposed infections with less common mould pathogens are less frequently reported but should be considered, given the easy access of a myriad of airborne fungi to the respiratory tract and underlying severe COVID-19-induced lung damage. Infections include those due to the Mucorales, Fusarium, Scedosporium/Lomentospora, and dematiaceous moulds. Where a non-Aspergillus mould infection is suspected (e.g., poor response to anti-Aspergillus therapy), additional diagnostic evaluation of respiratory tract specimens for these agents is recommended, which may include extended mycological culture and non-culture-based PCR tests [12].

A review of the literature indicates that the majority of non-Aspergillus mould infections are caused by the Mucorales [89-91]. Notably, the number of case reports and small case series of COVID-19-associated mucormycosis (CAM) has increased substantially with the rise of infection with COVID-19 in India in mid 2021 with many infections developing in patients recovering from COVID-19 [92-95]. Only one case each of invasive fusariosis and mixed mould infection are reported [96,97] and as of yet, there are no reports of fungemia caused by mould pathogens.

Risk factors for the acquisition of non-Aspergillus mould infections are similar to those for CAPA. In addition, for CAM, poorly controlled diabetes mellitus and trauma, in addition to underlying haematologic malignancy and allogeneic haematopoietic stem-cell transplantation (HSCT), have comprised the majority of co-morbidities; all are well-established risks for these infections [98]. In patients with CAM without traditional risk factors, many had hypertension, had end-stage kidney disease, and had received corticosteroid treatment for COVID-19. A recent review of 41 cases of CAM showed that underlying diabetes was present in $94 \%$ of cases and associated with severe COVID-19 in 95\% cases [99], as did that of Selarka et al. of 47 patients across three centres (76.6\%, 91.55\%) [100]. As expected, corticosteroid use was a key risk for mucormycosis from resultant hyperglycaemia [101]. Furthermore, the high expression of ACE-2 receptors in pancreatic isolates with resultant insulin resistance may predispose to diabetes. The hyper-ferritinemic state and intracellular iron load of severe COVID-19 as well as the presence of endothelialitis poses risk for mucormycosis, as summarized in John et al. [99]. Contaminated medical supplies, equipment, and environmental factors have been suggested as risk factors for community and nosocomial CAM in India [102].

Case reports have identified that mucormycosis usually develops 10-14 days after hospitalisation and in some cases was detected only at postmortem. Clinical presentation comprises mostly rhino-orbital/rhino-orbital cerebral (ROCM) disease, which is typical of that seen in patients with diabetes mellitus. In contrast to CAPA, nearly all CAM infections have been classed as proven infections [99]. As invasive mucormycosis and fusariosis both share many common features with CAPA in critically ill COVID-19 patients, clinical vigilance is paramount in recognising these serious mimickers of CAPA where even in survivors, morbidity is high including loss of vision; in-hospital mortality was 49\% [99]. The absence of reports of coinfections with the Scedosporium/Lomentospora may reflect limitations in diagnostics. These pathogens are important in hospital epidemiology and should be considered in all vulnerable immunocompromised patients such as those with haematological malignancy, stem cell, and solid organ transplantation [103,104].

The diagnosis of non-Aspergillus mould infections follows similar principles to those for other IFDs $[98,105,106]$. Clinical suspicion should prompt appropriate imaging and examination of clinical specimens (sputum, tracheal aspirates, BAL fluid, skin lesions) by histology, direct microscopy, culture for fungi, and employment of antigen and NAATbased approaches. Fusarium and Scedosporium/Lomentospora may be isolated from blood cultures. On histological examination and direct microscopy, Mucorales demonstrate broad pauci-septate irregular hyphae, whilst other non-Aspergillus moulds appear more slender. The invasion of blood vessels and tissue can be seen with Grocott-Gomori's methenamine silver (GMS), haemotoxylin and eosin (H\&E) and Periodic-Acid Schiff (PAS) stains [98,107]. Identification of the pathogen by Matrix-Assisted Laser Desorption Ionization-Time of 
Flight Mass Spectrometry (MALDI-TOF MS) systems and DNA sequencing targeting the internal transcribed spacer region (ITS) or large ribosomal subunit may be necessary for species identification. Panfungal PCR may be attempted on tissue specimens to directly detect the pathogen $[98,105]$.

Approaches to imaging are dependent on the site of involvement; in cases of suspected CAM where there is lung involvement, it is expected that abnormalities typical of mucormycosis in other patient groups will be present (Table 2). On chest CT, these include ground glass opacities and mass lesions with or without cavitation and consolidation (see Figure 1, which shows some of these abnormal features). The reverse halo sign, considered to be pathognomonic of pulmonary mucormycosis, may or may not be evident. Vascular occlusion on chest angiography may be present. Detailed descriptions are beyond the scope of this review but can be found in a recent international guideline of managing mucormycosis [98]. In addition, where CAM is suspected, imaging of the sinuses and brain is essential as well as of other body sites as clinically indicated [98]. Imaging abnormalities in the lung for other mould infections may be expected to mimic both CAM and CAPA [105] (Table 2).

Similarly, the principles of prompt antifungal therapy and early surgical debridement apply as for other patients with these infections [98,105]; however, surgery may not be feasible in COVID-19 patients for the same reasons why performing diagnostic procedures such as bronchoscopy may be problematic. There are no data on the impact on patient outcomes of specific therapies in the setting of COVID-19. For Mucorales infections, a lipid amphotericin B formulation, typically liposomal amphotericin B, is recommended as first-line monotherapy, with isavuconazole and posaconazole being alternatives; both azoles may be used as salvage therapy. There is no evidence to indicate the survival benefits of either therapy with polyene-azole or polyene-echinocandin combinations. For invasive fusariosis, primary treatment with either voriconazole or a lipid amphotericin B formulation is appropriate; however, combination therapy with these two agents is frequently used because of the presence of severe disease and due to challenges in achieving therapeutic voriconazole levels. For the treatment of other uncommon mould infections, the reader is referred to the management recommendations by Hoenigl et al. [105].

\subsection{Endemic Mycoses}

Particularly in geographic regions where endemic mycoses occur, lung infection caused by agents of these mycoses may coexist with COVID-19. As for CAPA and other mould infections, diagnosis may be missed given the similarity of presentation. Patients with severe COVID-19 and/or those receiving significant immunosuppressive therapy may experience reactivation of dormant or past infection with an endemic fungus. The wide use of corticosteroids, specifically dexamethasone, or IL-6 inhibitors, and other immunosuppressants to treat severe COVID-19 increase the risk of symptomatic endemic mycoses, as summarised in Segrelles-calvo et al. [20].

At least three patients with Coccidioides and SARS-CoV-2 coinfection have been reported [108-110]. Infections may be subclinical and diagnosed during the recovery phase of COVID-19. Heaney et al. [111] have described possible social, demographic, and exposure risk factor interactions between coccidioidomycosis and COVID-19, focusing on racial and ethnic minorities and the role of geography [111]. In addition, chronic lung disease from coccidioidomycosis may increase the risk of severe COVID-19, and COVID-19 may increase the risk of reactivation of latent Coccidioides infection [111].

Four coinfections with Histoplasma and SARS-CoV-2 have been reported, all from South America [112-115], with three cases occurring in the context of HIV infection. As with PCP, opportunistic infections typically associated with HIV should be considered in the differential diagnosis in patients with suggestive radiological features even if they have received a COVID-19 diagnosis. The coinfection reported in a HIV-negative patient was in the setting of persistent pulmonary histoplasmosis when pulmonary imaging prompted SARS-CoV-2 testing [115]. Typical radiological abnormalities for the endemic mycoses are summarised in (Table 2) [116]. SARS-CoV-2 coinfections with other dimorphic fungi- 
Blastomyces, Emergomyces, Paracoccidioides, Sporothrix, or Talaromyces- have not yet been reported but would not be unexpected in the appropriate clinical context.

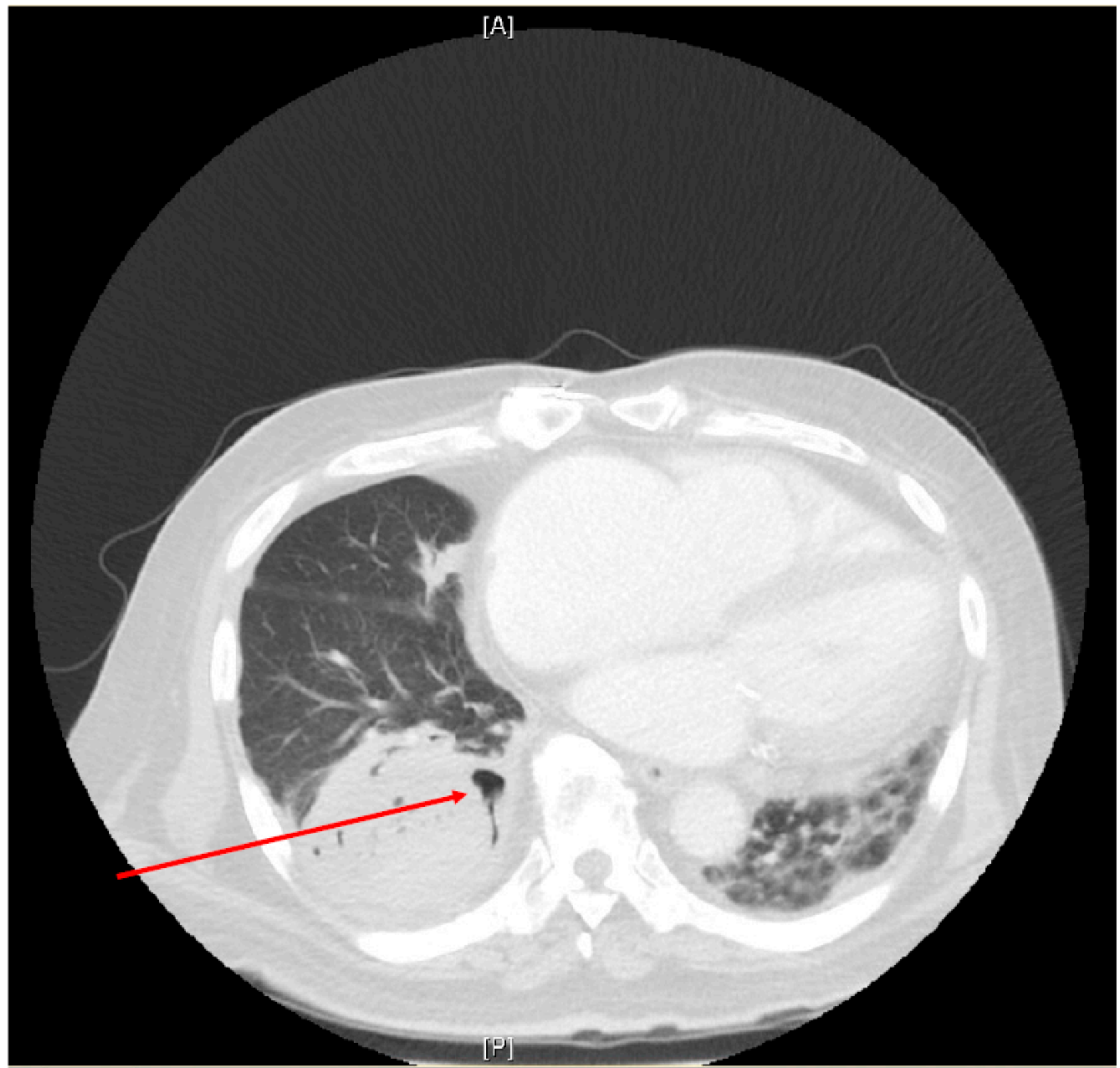

Figure 1. Chest Computer Tomography (CT) scan of a patient who had recovered from COVID-19 two months prior to presenting with new onset right-sided lower chest pain. Abnormalities on CT scan include a large mass lesion in the postero-basal segment of the right lower lobe with the beginnings of possible cavitation (arrow). A pleural effusion is present at the right lung base. The left lung shows consolidation with ground glass opacities. Fine needle aspiration of the right lower lobe mass yielded Rhizopus microsporus on culture with broad, pauci-septate irregular fungal hyphae seen on standard histopathological stains. [A]—anterior; $[\mathrm{P}]$ — posterior.

Diagnostic approaches should consider culture, microscopy, serologic antibody, and antigen tests on blood or urine and NAAT as appropriate. In most patients, diagnostic testing for coccidioidomycosis typically begins with antibody tests, with enzyme immunoassay (EIA) being most widely available, and less commonly antigen testing [117]. Antibody testing can also be used but is less reliable for histoplasmosis [118] and blastomycosis [119]. Treatment guidelines for endemic mycoses from the Infectious Diseases Society of America 
(IDSA) recommend that mild or moderate illness can be treated with triazole antifungals and severe disease can be treated with amphotericin B preparations followed by triazoles [119-121].

\subsection{Cryptococcosis}

Coinfection of SARS-CoV-2 and Cryptococcus has been uncommonly reported but may reflect under-recognition. Clinical manifestations include cryptococcemia, lung infection, and meningoencephalitis [122-124]; infection may also be disseminated [125,126]. Cryptococcosis may occur concurrently or present after recovery from COVID-19 and even diagnosed post mortem [124]. Patients had underlying immunocompromise and/or had received corticosteroid therapy for COVID-19, but cryptococcosis may also affect apparently immunocompetent hosts [123]. Imaging abnormalities in the lung in non-COVID-19 patients range from small nodules to large cryptococcomas or mass lesions, or non-specific pulmonary infiltrates [127]; whether these features will be borne out in the COVID-19 setting is uncertain. Imaging of other body sites should be guided by clinical decisions.

Laboratory-based diagnostic approaches are similar to those in non-COVID-19 patients, with histopathology, culture, and cryptococcal antigen tests being the cornerstone supported by molecular assays. In cases of suspected meningitis, a lumbar puncture should always be performed and cerebrospinal fluid examined by microscopy and culture [128]. Antifungal treatment and management of complications e.g., raised intracranial pressure, would be guided by recommendations of existing guidelines such as the IDSA [128]. A single patient has received isavuconazole therapy, rather than fluconazole, following induction therapy with liposomal amphotericin B [122]; there are sparse data on the role of this azole in treating patients with cryptococcosis.

\section{Approach to Diagnosing a Suspected Fungal Co-Infection in COVID-19 Patients}

The first step in managing any COVID-19-associated IFD is to identify high-risk patients and evaluate them for IFD. Broadly, patients with severe COVID-19 who require mechanical ventilation are at risk for CAPA $[23,53]$, other mould infections, and PCP. In addition, non-ventilated COVID-19 patients in the ICU who are experiencing clinical deterioration (e.g., pulmonary desaturation, sepsis-like syndrome) with no identifiable cause should also be evaluated for IFD, including for candidemia [129]. Additional risks such as diabetes mellitus in CAM and predisposing factors for IC are noted in their respective subsections above. Travel to an endemic region or prior infection could be a risk for infection or reactivation with an endemic mycosis during or after COVID-19 illness (Table 2). Whilst these factors may offer diagnostic clues, they cannot replace the importance of carefully working through the patient history and embarking on appropriate diagnostic work-up.

Diagnostic approaches are similar to those in non-COVID-19 patients, encompassing laboratory-based methods including histopathology, culture-based, serology, and NAAT -based methods, often in combination along with radiology to optimise the diagnostic yield. Table 2 summarises recommendations for the use of various methods to assist with the diagnosis of the major groups of fungal infections and includes CAPA for comparison. As described in the sections above, the histopathological examination of tissue specimens especially is strongly recommended where practicable, and culture remains a cornerstone for the diagnosis of many of these IFDs. As the agents of endemic mycoses are risk group 3 pathogens, the culture of specimens in suspected cases must be performed in a physical containment level 3 laboratory if attempted. Serological techniques remain useful in the diagnosis of cryptococcosis and for certain endemic mycoses (e.g., histoplasmosis). The increasing availability of NAAT assays for a large range of fungi has good potential to enable rapid accurate diagnosis either through panfungal or genus/species-specific approaches. Finally, the major imaging abnormalities that can be anticipated to be present in each group of IFD are summarised. 


\section{Conclusions}

As COVID-19 continues to spread worldwide, the emergence of VOC with vaccine escape potential, slow and uneven global uptake of vaccinations, and waning immunity in individuals vaccinated greater than 6 months ago has resulted in a largely susceptible population globally, making it important to continue to consider coinfections including fungi especially in the at-risk groups highlighted here in this review. Non-Aspergillus infections are a broad group of IFDs that may occur during or after the episode of COVID-19. Diagnostic algorithms are currently largely based on standard of care approaches practiced pre COVID-19, informed by guidelines, and encompassing multi-modal approaches. These will need to be updated as new learnings emerge from our growing experience of these infections in the setting of COVID-19. Antifungal and other management strategies are similar to those in non-COVID-19 patients but may be tempered by coincident comorbidities, accompanying drug use, and a whole patient approach.

Author Contributions: Conceptualisation, K.B., S.C.-A.C.; data review: K.B., S.C.-A.C., C.H., J.K.; writing-original draft preparation, K.B., C.H. and S.C.-A.C.; writing-review and editing, K.B., C.H., J.K. and S.C.-A.C. All authors have read and agreed to the published version of the manuscript.

Funding: This research received no external funding.

Institutional Review Board Statement: Not applicable.

Informed Consent Statement: Not applicable.

Data Availability Statement: Not applicable.

Conflicts of Interest: S.C.-A.C. declares the receipt of untied educational grants from MSD Australia and from F2G Ltd.

\section{References}

1. WHO. Director-General's Opening Remarks at the Media Briefing on COVID-19-11 March 2020. Available online: https:/ / www.who.int/director-general/speeches/detail/who-director-general-s-opening-remarks-at-the-media-briefing-oncovid-19---11-march-2020 (accessed on 8 September 2021).

2. The World Health Organization-WHO Lists Additional COVID-19 Vaccine for Emergency Use and Issues Interim Policy Recommendations. Available online: https://www.who.int/news/item/07-05-2021-who-lists-additional-covid-19-vaccinefor-emergency-use-and-issues-interim-policy-recommendations (accessed on 9 July 2021).

3. The World Health Organization-Tracking SARS-CoV-2 Variants. Available online: https://www.who.int/en/activities/trackingsars-cov-2-variants / (accessed on 1 September 2021).

4. Huang, C.; Wang, Y.; Li, X.; Ren, L.; Zhao, J.; Hu, Y.; Zhang, L.; Fan, G.; Xu, J.; Gu, X.; et al. Clinical Features of Patients Infected with 2019 Novel Coronavirus in Wuhan, China. Lancet 2020, 395, 497-506. [CrossRef]

5. Bohn, M.K.; Hall, A.; Sepiashvili, L.; Jung, B.; Steele, S.; Adeli, K. Pathophysiology of COVID-19: Mechanisms Underlying Disease Severity and Progression. Physiology 2020, 35, 288-301. [CrossRef] [PubMed]

6. Kim, D.; Quinn, J.; Pinsky, B.; Shah, N.H.; Brown, I. Rates of Co-Infection between SARS-CoV-2 and Other Respiratory Pathogens. JAMA J. Am. Med. Assoc. 2020, 323, 2085-2086. [CrossRef] [PubMed]

7. Tolle, L.B.; Standiford, T.J. Danger-Associated Molecular Patterns (DAMPs) in Acute Lung Injury. J. Pathol. 2013, 229, 145-156. [CrossRef] [PubMed]

8. $\quad$ van Arkel, A.L.E.; Rijpstra, T.A.; Belderbos, H.N.A.; van Wijngaarden, P.; Verweij, P.E.; Bentvelsen, R.G. COVID-19-Associated Pulmonary Aspergillosis. Am. J. Respir. Crit. Care Med. 2020, 202, 132-135. [CrossRef]

9. Hoenigl, M. Invasive Fungal Disease Complicating Coronavirus Disease 2019: When It Rains, It Spores. Clin. Infect. Dis. 2021, 73, e1645-e1648. [CrossRef]

10. Garcia-Vidal, C.; Sanjuan, G.; Moreno-García, E.; Puerta-Alcalde, P.; Garcia-Pouton, N.; Chumbita, M.; Fernandez-Pittol, M.; Pitart, C.; Inciarte, A.; Bodro, M.; et al. Incidence of Co-Infections and Superinfections in Hospitalized Patients with COVID-19: A Retrospective Cohort Study. Clin. Microbiol. Infect. 2021, 27, 83-88. [CrossRef]

11. Song, G.; Liang, G.; Liu, W. Fungal Co-Infections Associated with Global COVID-19 Pandemic: A Clinical and Diagnostic Perspective from China. Mycopathologia 2020, 185, 599-606. [CrossRef]

12. Gangneux, J.P.; Bougnoux, M.E.; Dannaoui, E.; Cornet, M.; Zahar, J.R. Invasive Fungal Diseases during COVID-19: We Should Be Prepared. J. De Mycol. Med. 2020, 30, 100971. [CrossRef]

13. Koehler, P.; Cornely, O.A.; Böttiger, B.W.; Dusse, F.; Eichenauer, D.A.; Fuchs, F.; Hallek, M.; Jung, N.; Klein, F.; Persigehl, T.; et al. COVID-19 Associated Pulmonary Aspergillosis. Mycoses 2020, 63, 528-534. [CrossRef] [PubMed] 
14. Lat, A.; Bhadelia, N.; Miko, B.; Furuya, E.Y.; Thompson, G.R. Invasive Aspergillosis after Pandemic (H1N1) 2009. Emerg. Infect. Dis. 2010, 16, 971-973. [CrossRef]

15. Magira, E.E.; Chemaly, R.F.; Jiang, Y.; Tarrand, J.; Kontoyiannis, D.P. Outcomes in Invasive Pulmonary Aspergillosis Infections Complicated by Respiratory Viral Infections in Patients with Hematologic Malignancies: A Case-Control Study. In Open Forum Infectious Diseases; Oxford University Press: Oxford, UK, 2019; Volume 6.

16. Schwartz, I.S.; Friedman, D.Z.P.; Zapernick, L.; Dingle, T.C.; Lee, N.; Sligl, W.; Zelyas, N.; Smith, S.W. High Rates of InfluenzaAssociated Invasive Pulmonary Aspergillosis May Not Be Universal: A Retrospective Cohort Study from Alberta, Canada. Clin. Infect. Dis. 2020, 71, 1760-1763. [CrossRef]

17. Huang, L.; Zhang, N.; Huang, X.; Xiong, S.; Feng, Y.; Zhang, Y.; Li, M.; Zhan, Q. Invasive Pulmonary Aspergillosis in Patients with Influenza Infection: A Retrospective Study and Review of the Literature. Clin. Respir. J. 2019, 13, 202-211. [CrossRef]

18. Schauwvlieghe, A.F.A.D.; Rijnders, B.J.A.; Philips, N.; Verwijs, R.; Vanderbeke, L.; van Tienen, C.; Lagrou, K.; Verweij, P.E.; van de Veerdonk, F.L.; Gommers, D.; et al. Invasive Aspergillosis in Patients Admitted to the Intensive Care Unit with Severe Influenza: A Retrospective Cohort Study. Lancet Respir. Med. 2018, 6, 782-792. [CrossRef]

19. Mouren, D.; Goyard, C.; Catherinot, E.; Givel, C.; Chabrol, A.; Tcherakian, C.; Longchampt, E.; Vargaftig, J.; Farfour, E.; Legal, A.; et al. COVID-19 and Pneumocystis Jirovecii Pneumonia: Back to the Basics. Respir. Med. Res. 2021, 79, 100814. [CrossRef] [PubMed]

20. Segrelles-Calvo, G.; de Saraújo, G.R.; Frases, S. Systemic Mycoses: A Potential Alert for Complications in COVID-19 Patients. Future Microbiol. 2020, 15, 1405-1413. [CrossRef]

21. Singh, A.K.; Singh, R.; Joshi, S.R.; Misra, A. Mucormycosis in COVID-19: A Systematic Review of Cases Reported Worldwide and in India. Diabetes Metab. Syndr. Clin. Res. Rev. 2021, 15, 102146. [CrossRef] [PubMed]

22. Al-Tawfiq, J.A.; Alhumaid, S.; Alshukairi, A.N.; Temsah, M.H.; Barry, M.; al Mutair, A.; Rabaan, A.A.; Al-Omari, A.; Tirupathi, R.; AlQahtani, M.; et al. COVID-19 and Mucormycosis Superinfection: The Perfect Storm. Infection 2021, 49, 833-853. [CrossRef] [PubMed]

23. Koehler, P.; Bassetti, M.; Chakrabarti, A.; Chen, S.C.A.; Colombo, A.L.; Hoenigl, M.; Klimko, N.; Lass-Flörl, C.; Oladele, R.O.; Vinh, D.C.; et al. Defining and Managing COVID-19-Associated Pulmonary Aspergillosis: The 2020 ECMM/ISHAM Consensus Criteria for Research and Clinical Guidance. Lancet Infect. Dis. 2021, 21, e149-e162. [CrossRef]

24. Guan, W.; Ni, Z.; Hu, Y.; Liang, W.; Ou, C.; He, J.; Liu, L.; Shan, H.; Lei, C.; Hui, D.S.C.; et al. Clinical Characteristics of Coronavirus Disease 2019 in China. N. Engl. J. Med. 2020, 382, 1708-1720. [CrossRef]

25. Advice on the Use of Masks in the Context of COVID-19. Interim Guidance. Geneva: World Health Organization. 2020. Available online: https:/ / www.who.int/Publications/i/Item/Advice-on-the-Use-of-Masks-in-the-Community-during-Home-Care-andin-Healthcare-Settings-in-the-Context-of-the-Novel-Coronavirus-(2019-Ncov)-Outbreak (accessed on 8 September 2021).

26. Zhou, P.; Yang, X.-L.; Wang, X.G.; Hu, B.; Zhang, L.; Zhang, W.; Si, H.R.; Zhu, Y.; Li, B.; Huang, C.L.; et al. A Pneumonia Outbreak Associated with a New Coronavirus of Probable Bat Origin. Nature 2020, 579, 270-273. [CrossRef]

27. Li, M.Y.; Li, L.; Zhang, Y.; Wang, X.S. Expression of the SARS-CoV-2 Cell Receptor Gene ACE2 in a Wide Variety of Human Tissues. Infect. Dis. Poverty 2020, 9, 1-7. [CrossRef]

28. Peacock, T.P.; Goldhill, D.H.; Zhou, J.; Baillon, L.; Frise, R.; Swann, O.C.; Kugathasan, R.; Penn, R.; Brown, J.C.; Sanchez-David, R.Y.; et al. The Furin Cleavage Site in the SARS-CoV-2 Spike Protein Is Required for Transmission in Ferrets. Nat. Microbiol. 2021, 6, 899-909. [CrossRef] [PubMed]

29. Hwang, D.M.; Chamberlain, D.W.; Poutanen, S.M.; Low, D.E.; Asa, S.L.; Butany, J. Pulmonary Pathology of Severe Acute Respiratory Syndrome in Toronto. Mod. Pathol. 2005, 18, 1-10. [CrossRef]

30. Zhang, H.; Zhou, P.; Wei, Y.; Yue, H.; Wang, Y.; Hu, M.; Zhang, S.; Cao, T.; Yang, C.; Li, M.; et al. Histopathologic Changes and SARS-CoV-2 Immunostaining in the Lung of a Patient With COVID-19. Ann. Intern. Med. 2020, 172, 629-632. [CrossRef] [PubMed]

31. Soy, M.; Keser, G.; Atagündüz, P.; Tabak, F.; Atagündüz, I.; Kayhan, S. Cytokine Storm in COVID-19: Pathogenesis and Overview of Anti-Inflammatory Agents Used in Treatment. Clin. Rheumatol. 2020, 39, 2085-2094. [CrossRef] [PubMed]

32. Yoshikawa, T.; Hill, T.; Li, K.; Peters, C.J.; Tseng, C.-T.K. Severe Acute Respiratory Syndrome (SARS) Coronavirus-Induced Lung Epithelial Cytokines Exacerbate SARS Pathogenesis by Modulating Intrinsic Functions of Monocyte-Derived Macrophages and Dendritic Cells. J. Virol. 2009, 83, 3039-3048. [CrossRef]

33. Channappanavar, R.; Zhao, J.; Perlman, S. T Cell-Mediated Immune Response to Respiratory Coronaviruses. Immunol. Res. 2014, 59, 118-128. [CrossRef]

34. Fujimoto, I.; Pan, J.; Takizawa, T.; Nakanishi, Y. Virus Clearance through Apoptosis-Dependent Phagocytosis of Influenza A Virus-Infected Cells by Macrophages. J. Virol. 2000, 74, 3399-3403. [CrossRef]

35. Small, B.A.; Dressel, S.A.; Lawrence, C.W.; Drake Iii, D.R.; Stoler, M.H.; Enelow, R.I.; Braciale, T.J. CD8 T Cell-Mediated Injury In Vivo Progresses in the Absence of Effector T Cells; Rockefeller University Press: New York, NY, USA, 2001; Volume 194.

36. Liu, S.; Su, X.; Pan, P.; Zhang, L.; Hu, Y.; Tan, H.; Wu, D.; Liu, B.; Li, H.; Li, H.; et al. Neutrophil Extracellular Traps Are Indirectly Triggered by Lipopolysaccharide and Contribute to Acute Lung Injury. Sci. Rep. 2016, 6, 37252. [CrossRef]

37. Mehta, P.; McAuley, D.F.; Brown, M.; Sanchez, E.; Tattersall, R.S.; Manson, J.J. COVID-19: Consider Cytokine Storm Syndromes and Immunosuppression. Lancet 2020, 395, 1033-1034. [CrossRef] 
38. The RECOVERY Collaborative Group. Dexamethasone in Hospitalized Patients with Covid-19. N. Engl. J. Med. 2021, 384, 693-704. [CrossRef]

39. Zhang, W.; Zhao, Y.; Zhang, F.; Wang, Q.; Li, T.; Liu, Z.; Wang, J.; Qin, Y.; Zhang, X.; Yan, X.; et al. The Use of Anti-Inflammatory Drugs in the Treatment of People with Severe Coronavirus Disease 2019 (COVID-19): The Experience of Clinical Immunologists from China. Clin. Immunol. 2020, 214, 108393. [CrossRef]

40. Baddley, J.W.; Thompson, G.R.; Chen, S.C.-A.; White, P.L.; Johnson, M.D.; Nguyen, H.; Schwartz, I.S.; Spec, A.; Ostrosky-Zeichner, L.; Jackson, B.R.; et al. COVID-19-Associated Invasive Fungal Infection. Open Forum Infect. Dis. 2021, ofab510. [CrossRef] [PubMed]

41. Kayaaslan, B.; Eser, F.; Kaya Kalem, A.; Bilgic, Z.; Asilturk, D.; Hasanoglu, I.; Ayhan, M.; Tezer Tekce, Y.; Erdem, D.; Turan, S.; et al. Characteristics of Candidemia in COVID-19 Patients; Increased Incidence, Earlier Occurrence and Higher Mortality Rates Compared to Non-COVID-19 Patients. Mycoses 2021, 64, 1083-1091. [CrossRef] [PubMed]

42. Stuck, A.E.; Minder, C.E.; Frey, F.J. Risk of Infectious Complications in Patients Taking Glucocorticosteroids. Clin. Infect. Dis. 1989, 11, 954-963. [CrossRef]

43. OLUMIANT (Baricitinib). Tablets FDA Product Insert Reference ID: 4271150. Available online: https://www.Accessdata.Fda. gov/Drugsatfda_docs/Label/2018/207924s000lbl.Pdf (accessed on 17 September 2021).

44. Sanchez, G.A.M.; Reinhardt, A.; Ramsey, S.; Wittkowski, H.; Hashkes, P.J.; Berkun, Y.; Schalm, S.; Murias, S.; Dare, J.A.; Brown, D.; et al. JAK1/2 Inhibition with Baricitinib in the Treatment of Autoinflammatory Interferonopathies. J. Clin. Investig. 2018, 128, 3041-3052. [CrossRef]

45. Kremer, J.; Li, Z.-G.; Hall, S.; Fleischmann, R.; Genovese, M.; Martin-Mola, E.; Isaacs, J.D.; Gruben, D.; Wallenstein, G.; Krishnaswami, S.; et al. Tofacitinib in Combination with Nonbiologic Disease-Modifying Antirheumatic Drugs in Patients with Active Rheumatoid Arthritis. Ann. Intern. Med. 2013, 159, 253. [CrossRef]

46. Cohen, S.B.; Tanaka, Y.; Mariette, X.; Curtis, J.R.; Lee, E.B.; Nash, P.; Winthrop, K.L.; Charles-Schoeman, C.; Thirunavukkarasu, K.; DeMasi, R.; et al. Long-Term Safety of Tofacitinib for the Treatment of Rheumatoid Arthritis up to 8.5 Years: Integrated Analysis of Data from the Global Clinical Trials. Ann. Rheum. Dis. 2017, 76, 1253-1262. [CrossRef] [PubMed]

47. Vallabhaneni, S.; Chiller, T.M. Fungal Infections and New Biologic Therapies. Curr. Rheumatol. Rep. 2016, 18, 1-10. [CrossRef]

48. Campbell, L.; Chen, C.; Bhagat, S.S.; Parker, R.A.; Östör, A.J.K. Risk of Adverse Events Including Serious Infections in Rheumatoid Arthritis Patients Treated with Tocilizumab: A Systematic Literature Review and Meta-Analysis of Randomized Controlled Trials. Rheumatology 2011, 50, 552-562. [CrossRef] [PubMed]

49. Schiff, M.H.; Kremer, J.M.; Jahreis, A.; Vernon, E.; Isaacs, J.D.; van Vollenhoven, R.F. Integrated Safety in Tocilizumab Clinical Trials. Arthritis Res. Ther. 2011, 13, R141. [CrossRef] [PubMed]

50. KEVZARA®(Sarilumab). Full Prescribing Information (SAI-FPLR-SL-APR18a). Available online: https://Products.Sanofi.Us / Kevzara/Kevzara.pdf (accessed on 17 November 2021).

51. Permpalung, N.; Chiang, T.P.-Y.; Massie, A.B.; Zhang, S.X.; Avery, R.K.; Nematollahi, S.; Ostrander, D.; Segev, D.L.; Marr, K.A. Coronavirus Disease 2019-Associated Pulmonary Aspergillosis in Mechanically Ventilated Patients. Clin. Infect. Dis. 2021, ciab223. [CrossRef] [PubMed]

52. Bartoletti, M.; Pascale, R.; Cricca, M.; Rinaldi, M.; Maccaro, A.; Bussini, L.; Fornaro, G.; Tonetti, T.; Pizzilli, G.; Francalanci, E.; et al. Epidemiology of Invasive Pulmonary Aspergillosis among COVID-19 Intubated Patients: A Prospective Study. Clin. Infect. Dis. 2021, 73, e3606-e3614. [CrossRef]

53. Salmanton-García, J.; Sprute, R.; Stemler, J.; Bartoletti, M.; Dupont, D.; Valerio, M.; Garcia-Vidal, C.; Falces-Romero, I.; Machado, M.; de la Villa, S.; et al. COVID-19-Associated Pulmonary Aspergillosis, March-August 2020. Emerg. Infect. Dis. 2021, 27, 1077-1086. [CrossRef] [PubMed]

54. Alanio, A.; Dellière, S.; Fodil, S.; Bretagne, S.; Mégarbane, B. Prevalence of Putative Invasive Pulmonary Aspergillosis in Critically Ill Patients with COVID-19. Lancet Respir. Med. 2020, 8, e48-e49. [CrossRef]

55. White, P.L.; Dhillon, R.; Cordey, A.; Hughes, H.; Faggian, F.; Soni, S.; Pandey, M.; Whitaker, H.; May, A.; Morgan, M.; et al. A National Strategy to Diagnose Coronavirus Disease 2019-Associated Invasive Fungal Disease in the Intensive Care Unit. Clin. Infect. Dis. 2021, 73, e1634-e1644. [CrossRef]

56. Blot, S.I.; Taccone, F.S.; van den Abeele, A.M.; Bulpa, P.; Meersseman, W.; Brusselaers, N.; Dimopoulos, G.; Paiva, J.A.; Misset, B.; Rello, J.; et al. A Clinical Algorithm to Diagnose Invasive Pulmonary Aspergillosis in Critically Ill Patients. Am. J. Respir. Crit. Care Med. 2012, 186, 56-64. [CrossRef]

57. Nasir, N.; Mahmood, F.; Habib, K.; Khanum, I.; Jamil, B. Tocilizumab for COVID-19 Acute Respiratory Distress Syndrome: Outcomes Assessment Using the WHO Ordinal Scale. Cureus 2020, 12, e12290. [CrossRef]

58. Borman, A.M.; Palmer, M.D.; Fraser, M.; Patterson, Z.; Mann, C.; Oliver, D.; Linton, C.J.; Gough, M.; Brown, P.; Dzietczyk, A.; et al. COVID-19-Associated Invasive Aspergillosis: Data from the UK National Mycology Reference Laboratory. J. Clin. Microbiol. 2021, 59, e02136-20. [CrossRef]

59. Nucci, M.; Barreiros, G.; Guimarães, L.F.; Deriquehem, V.A.S.; Castiñeiras, A.C.; Nouér, S.A. Increased Incidence of Candidemia in a Tertiary Care Hospital with the COVID-19 Pandemic. Mycoses 2021, 64, 152-156. [CrossRef]

60. Posteraro, B.; Torelli, R.; Vella, A.; Leone, P.M.; de Angelis, G.; de Carolis, E.; Ventura, G.; Sanguinetti, M.; Fantoni, M. PanEchinocandin-Resistant Candida Glabrata Bloodstream Infection Complicating Covid-19: A Fatal Case Report. J. Fungi 2020, 6, 163. [CrossRef] 
61. Chen, N.; Zhou, M.; Dong, X.; Qu, J.; Gong, F.; Han, Y.; Qiu, Y.; Wang, J.; Liu, Y.; Wei, Y.; et al. Epidemiological and Clinical Characteristics of 99 Cases of 2019 Novel Coronavirus Pneumonia in Wuhan, China: A Descriptive Study. Lancet 2020, 395, 507-513. [CrossRef]

62. Meijer, E.F.J.; Dofferhoand, A.S.M.; Meis, J.F.; Hoiting, O.; Buil, J.B. Azole-Resistant COVID-19-Associated Pulmonary Aspergillosis in an Immunocompetent Host: A Case Report. J. Fungi 2020, 6, 79. [CrossRef] [PubMed]

63. Arastehfar, A.; Carvalho, A.; Hong Nguyen, M.; Hedayati, M.T.; Netea, M.G.; Perlin, D.S.; Hoenigl, M. Covid-19-Associated Candidiasis (Cac): An Underestimated Complication in the Absence of Immunological Predispositions? J. Fungi 2020, 6, 211. [CrossRef] [PubMed]

64. Ghosh, A.; Sarkar, A.; Paul, P.; Patel, P. The Rise in Cases of Mucormycosis, Candidiasis and Aspergillosis amidst COVID-19. Fungal Biol. Rev. 2021, 38, 67-91. [CrossRef] [PubMed]

65. Riche, C.V.W.; Cassol, R.; Pasqualotto, A.C. Is the Frequency of Candidemia Increasing in Covid-19 Patients Receiving Corticosteroids? J. Fungi 2020, 6, 286. [CrossRef]

66. Macauley, P.; Epelbaum, O. Epidemiology and Mycology of Candidaemia in Non-Oncological Medical Intensive Care Unit Patients in a Tertiary Center in the United States: Overall Analysis and Comparison between Non-COVID-19 and COVID-19 Cases. Mycoses 2021, 64, 634-640. [CrossRef] [PubMed]

67. Seagle, E.E.; Jackson, B.R.; Lockhart, S.R.; Georgacopoulos, O.; Nunnally, N.S.; Roland, J.; Barter, D.M.; Johnston, H.L.; Czaja, C.A.; Kayalioglu, H.; et al. The Landscape of Candidemia during the Coronavirus Disease 2019 (COVID-19) Pandemic. Clin. Infect. Dis. 2021, ciab562. [CrossRef]

68. Denny, S.; Abdolrasouli, A.; Elamin, T.; Gonzalo, X.; Charani, E.; Patel, A.; Donaldson, H.; Hughes, S.; Armstrong-James, D.; Moore, L.S.; et al. A Retrospective Multicenter Analysis of candidaemia among COVID-19 Patients during the First UK Pandemic. J. Infect. 2021, 82, 288-290. [CrossRef] [PubMed]

69. Mulet Bayona, J.V.; Tormo Palop, N.; Salvador García, C.; Fuster Escrivá, B.; Chanzá Aviñó, M.; Ortega García, P.; Gimeno Cardona, C. Impact of the SARS-CoV-2 Pandemic in Candidaemia, Invasive Aspergillosis and Antifungal Consumption in a Tertiary Hospital. J. Fungi 2021, 7, 440. [CrossRef]

70. Prestel, C.; Anderson, E.; Forsberg, K.; Lyman, M.; de Perio, M.A.; Kuhar, D.; Edwards, K.; Rivera, M.; Shugart, A.; Walters, M.; et al. MMWR, Candida Auris Outbreak in a COVID-19 Specialty Care Unit-Florida, July-August 2020. Morb. Mortal. Wkly. Rep. 2019, 70, 56. [CrossRef]

71. Donnelly, J.P.; Chen, S.C.; Kauffman, C.A.; Steinbach, W.J.; Baddley, J.W.; Verweij, P.E.; Clancy, C.J.; Wingard, J.R.; Lockhart, S.R.; Groll, A.H.; et al. Revision and Update of the Consensus Definitions of Invasive Fungal Disease from the European Organization for Research and Treatment of Cancer and the Mycoses Study Group Education and Research Consortium. Clin. Infect. Dis. 2020, 71, 1367-1376. [CrossRef] [PubMed]

72. Giacobbe, D.R.; Mikulska, M.; Tumbarello, M.; Furfaro, E.; Spadaro, M.; Losito, A.R.; Mesini, A.; de Pascale, G.; Marchese, A.; Bruzzone, M.; et al. Combined Use of Serum (1,3)- $\beta$-d-Glucan and Procalcitonin for the Early Differential Diagnosis between Candidaemia and Bacteraemia in Intensive Care Units. Crit. Care 2017, 21, 1-9. [CrossRef] [PubMed]

73. Posteraro, B.; Tumbarello, M.; de Pascale, G.; Liberto, E.; Vallecoccia, M.S.; de Carolis, E.; di Gravio, V.; Trecarichi, E.M.; Sanguinetti, M.; Antonelli, M. (1,3)- $\beta$-d-Glucan-Based Antifungal Treatment in Critically Ill Adults at High Risk of Candidaemia: An Observational Study. J. Antimicrob. Chemother. 2016, 71, 2262-2269. [CrossRef]

74. Pappas, P.G.; Kauffman, C.A.; Andes, D.R.; Clancy, C.J.; Marr, K.A.; Ostrosky-Zeichner, L.; Reboli, A.C.; Schuster, M.G.; Vazquez, J.A.; Walsh, T.J.; et al. Executive Summary: Clinical Practice Guideline for the Management of Candidiasis: 2016 Update by the Infectious Diseases Society of America. Clin. Infect. Dis. 2015, 62, 409-417. [CrossRef] [PubMed]

75. Jeican, I.I.; Inișca, P.; Gheban, D.; Tăbăran, F.; Aluaș, M.; Trombitas, V.; Cristea, V.; Crivii, C.; Junie, L.M.; Albu, S. COVID-19 and Pneumocystis Jirovecii Pulmonary Coinfection—the First Case Confirmed through Autopsy. Medicina 2021, 57, 302. [CrossRef] [PubMed]

76. de Francesco, M.A.; Alberici, F.; Bossini, N.; Scolari, F.; Pascucci, F.; Tomasoni, G.; Caruso, A. Pneumocystis Jirevocii and SARS-CoV-2 Co-Infection: A Common Feature in Transplant Recipients? Vaccines 2020, 8, 544. [CrossRef]

77. Chong, W.H.; Saha, B.K.; Chopra, A. Narrative Review of the Relationship between COVID-19 and PJP: Does It Represent Coinfection or Colonization? Infection 2021, 49, 1079-1090. [CrossRef] [PubMed]

78. Mang, S.; Kaddu-Mulindwa, D.; Metz, C.; Becker, A.; Seiler, F.; Smola, S.; Maßmann, A.; Becker, S.L.; Papan, C.; Bals, R.; et al Pneumocystis Jirovecii Pneumonia and Severe Acute Respiratory Syndrome Coronavirus 2 Coinfection in a Patient With Newly Diagnosed HIV-1 Infection. Clin. Infect. Dis. Off. Publ. Infect. Dis. Soc. Am. 2021, 72, 1487-1489. [CrossRef]

79. Coleman, H.; Snell, L.B.; Simons, R.; Douthwaite, S.T.; Lee, M.J. Coronavirus Disease 2019 and Pneumocystis Jirovecii Pneumonia: A Diagnostic Dilemma in HIV. AIDS 2020, 34, 1258-1260. [CrossRef] [PubMed]

80. Menon, A.A.; Berg, D.D.; Brea, E.J.; Deutsch, A.J.; Kidia, K.K.; Thurber, E.G.; Polsky, S.B.; Yeh, T.; Duskin, J.A.; Holliday, A.M.; et al. A Case of COVID-19 and Pneumocystis Jirovecii Coinfection. Am. J. Respir. Crit. Care Med. 2020, 202, 136-138. [CrossRef]

81. Blaize, M.; Mayaux, J.; Luyt, C.E.; Lampros, A.; Fekkar, A. COVID-19-Related Respiratory Failure and Lymphopenia Do Not Seem Associated with Pneumocystosis. Am. J. Respir. Crit. Care Med. 2021, 202, 1734-1736. [CrossRef] [PubMed]

82. Alanio, A.; Dellière, S.; Voicu, S.; Bretagne, S.; Mégarbane, B. The Presence of Pneumocystis Jirovecii in Critically Ill with COVID-19. J. Infect. 2021, 82, 114-116. [CrossRef] [PubMed] 
83. Gerber, V.; Ruch, Y.; Chamaraux-Tran, T.N.; Oulehri, W.; Schneider, F.; Lindner, V.; Greigert, V.; Denis, J.; Brunet, J.; Danion, F. Detection of Pneumocystis Jirovecii in Patients with Severe Covid-19: Diagnostic and Therapeutic Challenges. J. Fungi 2021, 7, 585. [CrossRef]

84. Pagano, L.; Fianchi, L.; Mele, L.; Girmenia, C.; Offidani, M.; Ricci, P.; Mitra, M.E.; Picardi, M.; Caramatti, C.; Piccaluga, P.; et al. Pneumocystis Carinii Pneumonia in Patients with Malignant Haematological Diseases: 10 Years' Experience of Infection in GIMEMA Centres. Br. J. Haematol. 2002, 117, 379-386. [CrossRef] [PubMed]

85. Szydłowicz, M.; Matos, O. Pneumocystis Pneumonia in the COVID-19 Pandemic Era: Similarities and Challenges. Trends Parasitol. 2021, 37, 859-862. [CrossRef]

86. Alanio, A.; Hauser, P.M.; Lagrou, K.; Melchers, W.J.G.; Helweg-Larsen, J.; Matos, O.; Cesaro, S.; Maschmeyer, G.; Einsele, H.; Donnelly, J.P.; et al. ECIL Guidelines for the Diagnosis of Pneumocystis Jirovecii Pneumonia in Patients with Haematological Malignancies and Stem Cell Transplant Recipients. J. Antimicrob. Chemother. 2016, 71, 2386-2396. [CrossRef]

87. Maschmeyer, G.; Helweg-Larsen, J.; Pagano, L.; Robin, C.; Cordonnier, C.; Schellongowski, P.; Akova, M.; Aljurf, M.; Averbuch, D.; Barnes, R.; et al. ECIL Guidelines for Treatment of Pneumocystis Jirovecii Pneumonia in Non-HIV-Infected Haematology Patients. J. Antimicrob. Chemother. 2016, 71, 2405-2413. [CrossRef]

88. Gentile, I.; Viceconte, G.; Lanzardo, A.; Zotta, I.; Zappulo, E.; Pinchera, B.; Scotto, R.; Schiano Moriello, N.; Foggia, M.; Giaccone, A.; et al. Pneumocystis Jirovecii Pneumonia in Non-HIV Patients Recovering from COVID-19: A Single-Center Experience. Int. J. Environ. Res. Public Health 2021, 18, 11399. [CrossRef]

89. Mehta, S.; Pandey, A. Rhino-Orbital Mucormycosis Associated With COVID-19. Cureus 2020, 12, e10726. [CrossRef]

90. Pasero, D.; Sanna, S.; Liperi, C.; Piredda, D.; Branca, G.P.; Casadio, L.; Simeo, R.; Buselli, A.; Rizzo, D.; Bussu, F.; et al. A Challenging Complication Following SARS-CoV-2 Infection: A Case of Pulmonary Mucormycosis. Infection 2020, 49, 1055-1060. [CrossRef]

91. do Monte, E.S.; dos Santos, M.E.L.; Ribeiro, I.B.; de Oliveira Luz, G.; Baba, E.R.; Hirsch, B.S.; Funari, M.P.; de Moura, E.G.H. Rare and Fatal Gastrointestinal Mucormycosis (Zygomycosis) in a COVID-19 Patient: A Case Report. Clin. Endosc. 2020, 53, 746-749. [CrossRef]

92. Garg, D.; Muthu, V.; Sehgal, I.S.; Ramachandran, R.; Kaur, H.; Bhalla, A.; Puri, G.D.; Chakrabarti, A.; Agarwal, R. Coronavirus Disease (Covid-19) Associated Mucormycosis (CAM): Case Report and Systematic Review of Literature. Mycopathologia 2021, 186, 289-298. [CrossRef]

93. Sarkar, S.; Gokhale, T.; Choudhury, S.; Deb, A. COVID-19 and Orbital Mucormycosis. Indian J. Ophthalmol. 2021, 69, 1002-1004. [PubMed]

94. Sen, M.; Lahane, S.; Lahane, T.P.; Parekh, R.; Honavar, S.G. Mucor in a Viral Land: A Tale of Two Pathogens. Indian J. Ophthalmol. 2021, 69, 244-252. [CrossRef]

95. Revannavar, S.M.; Supriya, P.; Samaga, L.; Vineeth, K. COVID-19 Triggering Mucormycosis in a Susceptible Patient: A New Phenomenon in the Developing World? BMJ Case Rep. 2021, 14, e241663. [CrossRef] [PubMed]

96. Bellanger, A.P.; Navellou, J.C.; Lepiller, Q.; Brion, A.; Brunel, A.S.; Millon, L.; Berceanu, A. Mixed Mold Infection with Aspergillus Fumigatus and Rhizopus Microsporus in a Severe Acute Respiratory Syndrome Coronavirus 2 (SARS-CoV-2) Patient. Infect. Dis. Now 2021, 51, 633-635. [CrossRef] [PubMed]

97. Poignon, C.; Blaize, M.; Vezinet, C.; Lampros, A.; Monsel, A.; Fekkar, A. Invasive Pulmonary Fusariosis in an Immunocompetent Critically Ill Patient with Severe COVID-19. Clin. Microbiol. Infect. 2020, 26, 1582-1584. [CrossRef]

98. Cornely, O.A.; Alastruey-Izquierdo, A.; Arenz, D.; Chen, S.C.A.; Dannaoui, E.; Hochhegger, B.; Hoenigl, M.; Jensen, H.E.; Lagrou, K.; Lewis, R.E.; et al. Global Guideline for the Diagnosis and Management of Mucormycosis: An Initiative of the European Confederation of Medical Mycology in Cooperation with the Mycoses Study Group Education and Research Consortium. Lancet Infect. Dis. 2019, 19, e405-e421. [CrossRef]

99. John, T.M.; Jacob, C.N.; Kontoyiannis, D.P. When Uncontrolled Diabetes Mellitus and Severe Covid-19 Converge: The Perfect Storm for Mucormycosis. J. Fungi 2021, 7, 298. [CrossRef]

100. Selarka, L.; Sharma, S.; Saini, D.; Sharma, S.; Batra, A.; Waghmare, V.T.; Dileep, P.; Patel, S.; Shah, M.; Parikh, T.; et al. Mucormycosis and COVID-19: An Epidemic within a Pandemic in India. Mycoses 2021, 64, 1253-1260. [CrossRef]

101. Lionakis, M.S.; Kontoyiannis, D.P. Glucocorticoids and Invasive Fungal Infections. Lancet 2003, 362, 1828-1838. [CrossRef]

102. Narayanan, S.; Chua, J.V.; Baddley, J.W. Coronavirus Disease 2019-Associated Mucormycosis: Risk Factors and Mechanisms of Disease. Clin. Infect. Dis. 2021, ciab726. [CrossRef] [PubMed]

103. Slavin, M.; van Hal, S.; Sorrell, T.C.; Lee, A.; Marriott, D.J.; Daveson, K.; Kennedy, K.; Hajkowicz, K.; Halliday, C.; Athan, E.; et al. Invasive Infections Due to Filamentous Fungi Other than Aspergillus: Epidemiology and Determinants of Mortality. Clin. Microbiol. Infect. 2015, 21, 490.e1-490.e10. [CrossRef] [PubMed]

104. Ramirez-Garcia, A.; Pellon, A.; Rementeria, A.; Buldain, I.; Barreto-Bergter, E.; Rollin-Pinheiro, R.; de Meirelles, J.V.; Xisto, M.I.D.S.; Ranque, S.; Havlicek, V.; et al. Scedosporium and Lomentospora: An Updated Overview of Underrated Opportunists. Med. Mycol. 2018, 56, S102-S125. [CrossRef] [PubMed]

105. Hoenigl, M.; Salmanton-García, J.; Walsh, T.J.; Nucci, M.; Neoh, C.F.; Jenks, J.D.; Lackner, M.; Sprute, R.; Al-Hatmi, A.M.S.; Bassetti, M.; et al. Global Guideline for the Diagnosis and Management of Rare Mould Infections: An Initiative of the European Confederation of Medical Mycology in Cooperation with the International Society for Human and Animal Mycology and the American Society for Microbiology. Lancet Infect. Dis. 2021, 21, e246-e257. [CrossRef] 
106. Chen, S.C.A.; Halliday, C.L.; Hoenigl, M.; Cornely, O.A.; Meyer, W. Scedosporium and Lomentospora Infections: Contemporary Microbiological Tools for the Diagnosis of Invasive Disease. J. Fungi 2021, 7, 23. [CrossRef]

107. Skiada, A.; Lass-Floerl, C.; Klimko, N.; Ibrahim, A.; Roilides, E.; Petrikkos, G. Challenges in the Diagnosis and Treatment of Mucormycosis. Med. Mycol. 2018, 56, S93-S101. [CrossRef]

108. Chang, C.C.; Senining, R.; Kim, J.; Goyal, R. An Acute Pulmonary Coccidioidomycosis Coinfection in a Patient Presenting With Multifocal Pneumonia With COVID-19. J. Investig. Med. High Impact Case Rep. 2020, 8, 2324709620972244. [CrossRef]

109. Shah, A.S.; Heidari, A.; Civelli, V.F.; Sharma, R.; Clark, C.S.; Munoz, A.D.; Ragland, A.S.; Johnson, R.H. The Coincidence of 2 Epidemics, Coccidioidomycosis and SARS-CoV-2: A Case Report. J. Investig. Med. High Impact Case Rep. 2020, 8, 2324709620930540. [CrossRef] [PubMed]

110. Krauth, D.S.; Jamros, C.M.; Rivard, S.C.; Olson, N.H.; Maves, R.C. Accelerated Progression of Disseminated Coccidioidomycosis Following SARS-CoV-2 Infection: A Case Report. Mil. Med. 2021, 186, 1254-1256. [CrossRef] [PubMed]

111. Heaney, A.K.; Head, J.R.; Broen, K.; Click, K.; Taylor, J.; Balmes, J.R.; Zelner, J.; Remais, J.V. Coccidioidomycosis and COVID-19 Co-Infection, United States, 2020. Emerg. Infect. Dis. 2021, 27, 1266-1273. [CrossRef] [PubMed]

112. Bertolini, M.; Mutti, M.F.; Barletta, J.A.E.; Falak, A.; Cuatz, D.; Sisto, A.; Ragusa, M.A.; Fernandez Claros, N.O.; Rolón, M.J. COVID-19 Associated with AIDS-Related Disseminated Histoplasmosis: A Case Report. Int. J. STD AIDS 2020, 31, 1222-1224. [CrossRef]

113. Messina, F.A.; Marin, E.; Caceres, D.H.; Romero, M.; Depardo, R.; Priarone, M.M.; Rey, L.; Vázquez, M.; Verweij, P.E.; Chiller, T.M.; et al. Coronavirus Disease 2019 (Covid-19) in a Patient with Disseminated Histoplasmosis and Hiv-a Case Report from Argentina and Literature Review. J. Fungi 2020, 6, 275. [CrossRef]

114. Basso, R.P.; Poester, V.R.; Benelli, J.L.; Stevens, D.A.; Zogbi, H.E.; Vasconcellos, I.C.D.S.; Pasqualotto, A.C.; Xavier, M.O. COVID19-Associated Histoplasmosis in an AIDS Patient. Mycopathologia 2021, 186, 109-112. [CrossRef]

115. Stasiak, C.E.S.; Cardoso, F.R.; de Almeida, S.A.; Rosado-de-Castro, P.H. Incidental Finding of COVID-19 Infection after [68Ga]GaPSMA-11 PET/CT Imaging in a Patient with Prostate Cancer. Eur. J. Nucl. Med. Mol. Imaging 2021, 48, 653-654. [CrossRef] [PubMed]

116. Azar, M.M.; Malo, J.; Hage, C.A. Endemic Fungi Presenting as Community-Acquired Pneumonia: A Review. Semin. Respir. Crit. Care Med. 2020, 41, 522-537. [CrossRef]

117. Malo, J.; Luraschi-Monjagatta, C.; Wolk, D.M.; Thompson, R.; Hage, C.A.; Knox, K.S. Update on the Diagnosis of Pulmonary Coccidioidomycosis. Ann. Am. Thorac. Soc. 2014, 11, 243-253. [CrossRef]

118. Azar, M.M.; Hage, C.A. Laboratory Diagnostics for Histoplasmosis. J. Clin. Microbiol. 2018, 56, 1612-1620. [CrossRef]

119. Chapman, S.W.; Dismukes, W.E.; Proia, L.A.; Bradsher, R.W.; Pappas, P.G.; Threlkeld, M.G.; Kauffman, C.A. Clinical Practice Guidelines for the Management of Blastomycosis: 2008 Update by the Infectious Diseases Society of America. Clin. Infect. Dis. 2008, 46, 1801-1812. [CrossRef] [PubMed]

120. Wheat, L.J.; Freifeld, A.G.; Kleiman, M.B.; Baddley, J.W.; McKinsey, D.S.; Loyd, J.E.; Kauffman, C.A. Clinical Practice Guidelines for the Management of Patients with Histoplasmosis: 2007 Update by the Infectious Diseases Society of America. Clin. Infect. Dis. 2007, 45, 807-825. [CrossRef] [PubMed]

121. Galgiani, J.N.; Ampel, N.M.; Blair, J.E.; Catanzaro, A.; Geertsma, F.; Hoover, S.E.; Johnson, R.H.; Kusne, S.; Lisse, J.; MacDonald, J.D.; et al. 2016 Infectious Diseases Society of America (IDSA) Clinical Practice Guideline for the Treatment of Coccidioidomycosis. Clin. Infect. Dis. 2016, 63, e112-e146. [CrossRef] [PubMed]

122. Cafardi, J.; Haas, D.; Lamarre, T.; Feinberg, J. Opportunistic Fungal Infection Associated with COVID-19. In Open Forum Infectious Diseases; Oxford University Press: Oxford, UK, 2021; Volume 8. [CrossRef]

123. Ghanem, H.; Sivasubramanian, G. Cryptococcus Neoformans Meningoencephalitis in an Immunocompetent Patient after COVID-19 Infection. Case Rep. Infect. Dis. 2021, 2021, 1-3. [CrossRef] [PubMed]

124. Passarelli, V.C.; Perosa, A.H.; de Souza Luna, L.K.; Conte, D.D.; Nascimento, O.A.; Ota-Arakaki, J.; Bellei, N. Detected SARS-CoV-2 in Ascitic Fluid Followed by Cryptococcemia: A Case Report. SN Compr. Clin. Med. 2020, 2, 2414-2418. [CrossRef] [PubMed]

125. Passerini, M.; Terzi, R.; Piscaglia, M.; Passerini, S.; Piconi, S. Disseminated Cryptococcosis in a Patient With Metastatic Prostate Cancer Who Died in the Coronavirus Disease 2019 (COVID-19) Outbreak. Cureus 2020, 12, e8254. [CrossRef]

126. Alegre-González, D.; Herrera, S.; Bernal, J.; Soriano, A.; Bodro, M. Disseminated Cryptococcus Neoformans Infection Associated to COVID-19. Med. Mycol. Case Rep. 2021, 34, 35-37. [CrossRef]

127. Chen, S.; Sorrell, T.; Nimmo, G.; Speed, B.; Currie, B.; Ellis, D.; Marriott, D.; Pfeiffer, T.; Parr, D.; Byth, K.; et al. Epidemiology and Host-and Variety-Dependent Characteristics of Infection Due to Cryptococcus Neoformans in Australia and New Zealand. Clin. Infect. Dis. 2000, 31, 499-508. [CrossRef]

128. Perfect, J.R.; Dismukes, W.E.; Dromer, F.; Goldman, D.L.; Graybill, J.R.; Hamill, R.J.; Harrison, T.S.; Larsen, R.A.; Lortholary, O.; Nguyen, M.H.; et al. Clinical Practice Guidelines for the Management of Cryptococcal Disease: 2010 Update by the Infectious Diseases Society of America. Clin. Infect. Dis. 2010, 50, 291-322. [CrossRef]

129. Armstrong-James, D.; Youngs, J.; Bicanic, T.; Abdolrasouli, A.; Denning, D.W.; Johnson, E.; Mehra, V.; Pagliuca, T.; Patel, B.; Rhodes, J.; et al. Confronting and Mitigating the Risk of COVID-19 Associated Pulmonary Aspergillosis. Eur. Respir. J. 2020, 56, 2002554. [CrossRef] 